Brazilian Journal of Political Economy, vol. 41, nº 4, pp. 679-699, October-December/2021

\title{
National Developmental State: the beginnings of historical-social procedurality and pioneering essays
}

\author{
Estado nacional-desenvolvimentista: primórdios \\ da processualidade histórica-social e ensaios pioneiros
}

ISAIAS ALBERTIN DE MORAES*,**

RESUMO: O trabalho procura contribuir com o avanço dos estudos acerca do Estado nacional e do desenvolvimento econômico. Para tanto, utilizou-se de uma abordagem transdisciplinar original e singular pautada na teoria sociológica de Pierre Bourdieu e na história econômica. Os procedimentos metodológicos foram pesquisa bibliográfica de análise histórica, concreta e indutiva da economia. Os resultados obtidos foram de que para a edificação de um Estado nacional-desenvolvimentista a sociedade, primeiramente, precisa estabelecer metacapital e metacampo imersos nos preceitos desenvolvimentistas e concentradores de soft power e de hard power para, posteriormente, executar o projeto de ampliação, de integração e de sofisticação da estrutura produtiva.

PALAVRAS-CHAVE: Economia do desenvolvimento; estado nacional-desenvolvimentista; história econômica.

ABSTRACT: This paper seeks to contribute to the advancement of studies on the National State and economic development. For that, I used an original and singular transdisciplinary approach based on Pierre Bourdieu's sociological theory and economic history. The methodological procedures were bibliographic research of historical and inductive analysis of the economy. The results obtained were that, for the construction of a National Developmental State, society, first, needs to establish meta-capital and meta-field immersed in the developmental precepts and concentrators of soft power and hard power to, subsequently, execute the project of expansion, integration and sophistication of the productive structure.

KEYWORDS: Development economics; developmental state; economic history. JEL Classification: N01; B10; H70.

\footnotetext{
* Researcher of the Núcleo de Extensão e Pesquisa em Economia Solidária, Criativa e Cidadania (NEPESC-Unesp), Araraquara-SP, Brasil. E-mail: isaias.a.moraes@unesp.br. Orcid: https://orcid. org/0000-0003-1839-803X. Submitted: 1/October/2020; Approved: 11/November/2020.

** Doutor em Ciências Sociais pela Unesp-Araraquara.
} 


\section{INTRODUCTION}

The present work starts from a fundamental premise: the formulation of the concept and the practical structuring of the State is something recent, gaining meaning and content only in the Renaissance - mid 14th century - and is strictly linked to contemporary economic development. Due to being a recent creation, the conceptual operationalization of the State is still under construction. However, one thing is a fact: it is not possible to understand economic development, its local and global process and the obstacles created by the structures that emerged in this movement, without understanding the State.

The essential characteristic of the historical-social procedurality ${ }^{1}$ that made possible the emergence of central economies and peripheral economies was the narrow and the complex interdependence between the constitution of the State and the market. The State, here, is the meta-field with its political., economic and social arrangements. The market, in turn, is the social organization through which offerors and claimants establish business relationships in order to carry out transactions, agreements or exchanges of goods and/or services.

The systematic action of the State in the market from the 16th century was based on an interdependence among the different parts of the new social structure that was emerging. This caused the transformations initiated in one of them eventually had repercussions in the others. This notion is fundamental., since it allows observing how certain regions and societies obtained an expansion, integration and sophistication of their productive structure and others have not. This established that there were societies with greater complexity and sophistication of the productive structure - later categorized as developed - and societies with low complexity and primary productive structure - called underdeveloped.

With this in mind, the research asked how it could contribute to the advancement of studies on the National State and economic development. The answer to this question was to present a rescue of the formation of the social structure called State, using instruments of sociology and economics, to understand its role in the process of economic development. Economic development is, roughly speaking, the joint pursuit of the State and the market to incorporate technical progress and increase the expansion, integration and sophistication of the productive structure in an economy. The hypothesis that the research raises is that for the construction of a National Developmental State society, first, needs to establish meta-capital and meta-field immersed in the developmental premises and concentrators of soft power and hard power to, in a second phase, execute the project of expansion, integration and sophistication of the productive structure.

\footnotetext{
${ }^{1}$ The article uses the concept of procedurality used by Marxists. In the words of Carcanholo (2013, p. 193), procedurality helps to describe "[...] how a given social structure unfolds over time, how the laws of functioning of a certain sociability are manifested in a time trajectory - manifestations that always have a historical determination".
} 
In order to carry out the proposed historical-social rescue, formulating and operating concepts and to validate the hypothesis, the article revisited the main works that address the theme. The methodological procedures for select such references were systematic and careful bibliographic research focused on the authors with historical., concrete and inductive analysis of the economy.

It is important to emphasize that the text does not have the scope to conduct a State of the Art research on the subject. The delimitation has the cut in the initial phase of the historical-social procedurality of building of the National Developmental State and its first essays and theoretical studies. Thus, the research does not have the ambition to cover all the successful experiences of a National Developmental State, nor to explain about recent studies on the subject, for further details in this perspective see: Chang (2004, 2008, 2009), Reinert (2007), Wade (1990), Rodrik (2005, 2007), Bresser-Pereira (2016a, 2017a, 2018), Amsden (2001).

The originality and uniqueness of the article, therefore, do not lie in the bibliographical research of the State of the Art, nor in the explanation and evaluation of the experiences of productive structural change for the economic development of some nations. The article innovates and particularizes itself because of the theoretical framework it uses to qualify, systematize and perpetuate the object of study, that is, the National Developmental State. The theoretical framework adopted is Pierre Bourdieu's sociological theory.

The theoretical framework is justified because Bourdieu manages to present an expanded conception of the concept of capital. Pierre Bourdieu's sociological theory points out the limitations of the concept of economic capital to explain the relationship and interdependence between State and market for economic development. In the historical-social procedurality that builds a National Developmental State, it is necessary to consider other forms of capital., such as social and cultural capital., in addition the economic.

The paper consists of two sections, besides the introduction and final remarks. The first section, briefly, outlined the historical-social procedurality for the theoretical-practical construction of the Nation-State and presented the theoretical framework adopted by the research. The second section analysed the pioneering essays and studies on the interdependence between State and market for economic development. The results of the research were that in order to build a National Developmental State, society, first, needs to establish meta-capital and meta-field immersed in the developmental precepts and concentrators of soft power and hard power to, in a second phase, execute the project of expansion, integration and sophistication of the productive structure.

\section{COMMUNITY, SOCIETY AND THE NATIONAL STATE}

The relationships among the varied communities have not always occurred based on the form of relations between sovereign and equal territorial States. This social form organized around State power is eminently modern and recent. Previously, 
there were communal relations built by affinities of consanguinity (family), territorial cohabitation (neighbors) and affective-spiritual (friends). According to Brancaleone $(2008$, p. 100), the origins of the community "[...] would rest on the consciousness of mutual dependence determined by the conditions of common life, by the shared space and by kinship". These patterns of community relations took place territorially in three spatial nuclei: home (family), commune-village (neighbors) and settlement (friends, community forms of sociability).

In the mid-14th century and with effect of the Capitalist Revolution ${ }^{2}$, there was, in Europe, a gradual transition from the rural to the urban way of life, allowing the change from feudalism to capitalism. This caused the organizational nuclei of the communities to change little by little. Kinship and neighbourhood circles have lost strength, feelings and community activities as well. Coexistence, which was previously based on habits, customs and spirituality in the community, began to be structured by convention, State policy and public opinion. The economy that was domestic, with production based on agriculture, gradually converted to a mercantilist, industrial model with rational and scientific planning (Tönnies, 1947).

The commercial exchanges and the advance of capitalism, especially from the 18th century with the advent of the Enlightenment and Modernism, caused the weakening of the ties permeated by consanguinity, customs, affections, and tradition. Consequently, relationships mediated by reason, calculation and interest such as labour, entrepreneurial and individual emerged more and more. Community activities, kinship, and neighbourhood circles lost their protagonist with the advance of capitalism and the development of cities. Legislation, science, mercantile commerce, industrial production and the existence of the State are associated with the advent of society to the detriment of communal organization.

According to Tönnies (1947), societies are structured by societal relations of individuals who are self-conscious of their interests and who coexist within a mercantile sociability oriented, in large part, by calculation, trafficking and contract. For Durkheim (1960), society is an organic whole where individuals connect through interdependent social relationships, composing the collective whole and participating in different beliefs. The legitimate contract among individuals established civil society and allowed the emergence of the modern State.

Historically, the emergence of the modern State can be marked by the consolidation of City-States governed as republics in northern Italy in the 14th century ${ }^{3}$. The Capitalist Revolution, which emerged at that time, made territorial spaces increas-

\footnotetext{
2 The article understands the Capitalist Revolution as the long period of time that allowed the change from the feudal system to capitalism. It began in northern Italy from the 14th century and completed in Great Britain with the formation of the Nation State and the Industrial Revolution at the end of the 18th century (Bresser-Pereira, 2017b).

${ }^{3}$ The ancient empires (Roman, Egyptian, Mongolian, Persian, Austro-Hungarian, among others) were essentially an instrument of the land-owning oligarchy, an armed force and a group that holds mysticalspiritual rhetoric. The main scope of the ancient empires was not trade, but war for the purpose of conquering land, looting wealth, collecting taxes and exploiting slave labor (Renan, 1997).
} 
ingly follow commercial legislation, rejecting the old traditional., religious and paternalistic ties that prevailed in the fiefdoms. In the City-States, financial and commercial operations were carried out, such as foreign exchange, debt settlement, credits, production for export, wholesale sales, etc. (Hunt, Sherman, 2005; BresserPereira, 2017b).

The need to expand production, regularize financial-commercial operations and the supply of manufactured goods, imposed by the expansion of trade, led merchantcapitalists to progressively assume control over the production process and influence political-social organization. The decline of medieval society brought more insecurity to trade and production, which grew significantly, so the merchant-capitalists were forced to encourage the creation of an administrative apparatus separate from society and holder of the legitimate monopoly on force. Post-medieval Europe invented the State in the form of absolute monarchies. These invested against private interests and the social., economic and political prerogatives of feudalism (Hunt, Sherman, 2005; Bresser-Pereira, 2017b).

In other words, the absolute monarchies of Europe unified political power, establishing stable bodies of bureaucratic officials and regular, centralized armies. Medieval political power, which was fragmented into intertwined sovereignties, was gradually dissipated by centralization and formation of the State. State power enabled the delimitation of fixed geographical boundaries and a more permanent capital flow, within the territorial logic. The Capitalist Revolution forced the construction of a national market and gradually imposed the capital-labor relationship.

At first, the State had an absolutist personality, with the personification of power in the figure of the monarch. Absolute sovereignty followed the king's patrimonial logic, preventing a clear separation between the public and private spheres. National sovereignty only arose with the weakening of power and rhetoric in favor of absolutism and the displacement of sovereignty from the monarch to the concept of nation. Power was depersonalized and began to identify with the people and the nation. The notion of sovereignty and authority was clearly associated with the public sphere (Hunt, Sherman, 2005; Bresser-Pereira, 2017b).

The nation is something recent and, according to Hobsbawm (2004), emerged from the Capitalist Revolution. Before, according to Renan (1997), there were groups of individuals and communities. According to Otto Bauer (2000), the nation is a politically organized society that shares a common history and destiny. For Bresser-Pereira (2017b, p. 171): “The concept of 'common destiny' is broad, but always involves three fundamental objectives: i) national autonomy or external security, ii) internal public order and iii) economic development".

The society that constitutes the nation may have - in addition to history and common destiny - a set of common cultural characteristics, traditions, language, customs and material and spiritual aspirations. The dominant element and subjective condition for nation building, however, is the desire to live collectively in search of converging interests and needs. It is a desire to live, so it is popular sovereignty and self-determination. Society, when constituting a nation, at a certain historical moment, became a people and began to be linked to a specific legal regime ordered 
by the State. As Bonavides (2008, p. 196) points out: “[...] the nation incorporates the legitimacy of the sovereign people by promulgating the sovereign constitutions of the social contract". In order to guarantee unity, nations were consolidated into territories to ensure their possession and sovereignty. The original landmark of the Nation-State is the Treaties of Westphalia in the 17th century (Castro, 2001).

Since the Peace of Westphália in 1648, the State has solidified its characteristics as a sovereign entity and above any other power present in society. After the Thirty Years' War and with the signing of the Westphalian Treaties, the "territorialization" of politics was established, which had been a trend since the 12th and 13th centuries in Europe. The Westphalian order to restoring peace in Europe, normalized the concept of State and national sovereignty. It grated the State supreme power, disapproving the limitation of State power by any other unit of power or authority within its national borders. After the Westphalian Treaties, an international framework was created that established the legal parity between the signatory territories that came to hold diplomatic duties among themselves (Castro, 2001).

The emergence of the modern State and, subsequently, the Nation-State caused several thinkers to develop theories about the concept, organization and functioning of the State. For example, the "reason of State" of Nicolas Machiavelli (1469-1527), the "leviathan" State of Thomas Hobbes (1588-1679), the State guaranteeing the property and individual rights of John Locke (1632-1704), the State with the "separation of powers" of the Baron of Montesquieu (1689-1755), the "popular sovereignty" of Jean-Jacques Rousseau (1712-1778), the "self-management" and anarchy of Pierre-Joseph Proudhon (1808-1865) are readings about the State that have impacted and still touch individuals and societies nowadays.

The conceptual formulation and operationalization of the State varies too much in scientific production focused on the theme. In a bibliographic review on the topic, it was noted that the most popular concept is from Max Weber: "The State is that human community that, within a given territory - this, the 'territory', is part of its characteristics - claims (successfully) the monopoly of legitimate physical coercion" (Weber, 1982, p. 98). Another widely popularized interpretation of the State is that of Karl Marx and Friedrich Engels. According to the authors, the State is:

[...] the form in which the individuals of a ruling class assert their common interests, and in which the whole civil society of an epoch is epitomised, it follows that all common institutions are set up with the help of the state and are given a political form. (Marx, Engels, 1998, p. 99)

In the view of Marx and Engels (2004, p. 15), the fathers of so-called Real Socialism, "[...] in general., the bourgeoisie has at last, since the establishment of Modern Industry and of the world market, conquered for itself, in the modern representative State, exclusive political sway". For the authors, after the Capitalist Revolution, "The executive of the modern state is but a committee for managing the common affairs of the whole bourgeoisie" (Marx, Engels, 2004, p. 15).

A more comprehensive approach to the concept of the State is presented by 
Pierre Bourdieu. The French sociologist claims that the State is nothing more than a well-founded illusion, an abstraction. For Bourdieu (1996, 2014), the State is actually a construction of agents and acts that incorporate institutions, forming what is called the Nation-State. In this abstraction, several categories of capital are concentrated, such as: coercion, economic, cultural., knowledge, social relations, legal., etc.

For Bourdieu (1977, 2007), capital is not limited to the accumulation of goods and economic wealth, but every resource or power that manifests itself in a social activity. Thus, in a society there are various forms of capital such as: economic capital (income, wages, wealth), cultural capital (knowledge, titles, qualifications) and social capital (social relations, contacts, groups).

For Bourdieu (1977, 2007), economic capital is only one of the capitals that pre-determine the struggle of individuals from their class position. Cultural capital can be defined as "useful knowledge" and has as much importance as economic capital. Cultural capital influences the formation of economic capital since the market and the State need individuals with knowledge and qualifications to generate wealth. Finally, there is social capital understood as secondary in relation to economic and cultural capital. This does not mean that Bourdieu $(1977,2007)$ underestimates the decisive factor for the individual success of social capital., but emphasizes that access to social relations, contacts and groups are determined by economic capital and cultural capital. For example, a proletariat - low economic capital and low cultural capital - would not be able to have the same conditions of social capital as a productive or financial capitalist.

The recognition of the different types of capital (economic, cultural and social) refers to a symbolic capital (prestige, honor, glory) that allows the identification of social agents in the fields. The agglomeration of profuse capital molds means that a specific meta-capital is structured with the potential to exert influence in all kinds of field, endorsing its hegemony over other fragmented capital categories.

The field, in Bourdieu's meta-theory $(1977,2007)$, is a symbolic space where disputes and conflicts of agents and their powers occur. In each field there is a symbolic power, for example in the field of the arts the symbolic struggle determines what is high-culture or what is mass culture; in the political field, it is defined what is populist, conservative or progressive politics; in the economic field, the struggle may be to specify what the role of the State in the economy, the market and what the concept of economic development would be. The field, therefore, is where the social position of agents is determined and where physical oppression, rhetoric and figures of "authority" are revealed through their greater or lesser volume of capital - resource or power.

The State, in Bourdieu's perception, represents a meta-field since "[...] in each field, both in its genesis and in its functioning, the State is present" (Bourdieu, 2014, p. 493).

It follows that the construction of the state proceeds apace with the construction of a field of power, defined as the space of play within which 
the holders of capital (of different species) struggle in particular for power over the state, that is, over the statist capital granting power over the different species of capital and over their reproduction (particularly through the school system). (Bourdieu, 1998, p. 48)

In consequence of all explain, the concept of State supports being summarized in one word: power. In order to be strengthened, the State needs to constantly reiterate its external and internal force, otherwise new parallel powers or external interference arise. There is no power vacuum. State power is the expression of power present in social forms of political intermediation, in civil society, in conciliation of social classes and is conducted by agents and acts composing the metacapital that operates in different forms of the field.

The State power, disseminated in the set of agents and acts that form the State, does not necessarily represent exclusively a certain social class, as described by Marx and Engels ${ }^{4}$. Society can aim at building a meta-field - which is the State based on class conciliation. The first theorists to advocate a corporatist State model, based on the conciliation of social classes, were the English socialists who developed Guild Socialism between the years 1906-1916. The main names are: Arthur Joseph Penty; George Douglas Howard Cole; Frederic W. Maitland and John N. Figgis (Torreggiani, 2016) ${ }^{5}$.

The power of the State, moreover, is not only reduced to the military with its capacity for physical coerce, as presupposes the conceptual formulation and operationalization of the State in Weber. The breadth of State power is greater, involving physical coercion and symbolic violence with ideological-cultural conditioning and persuasion. The State, therefore, has command power - physical coercion - and co-optive power - ideological-cultural conditioning and persuasion.

We truly believe that the categorization of State power, carried out by Joseph Samuel Nye Jr., is an interesting tool for understanding and supporting the argumentation proposed here. According to Nye Jr. (2004, 2010), the State has two essential forms of power: hard power and soft power. Hard power is understood by the use of intimidation and military and economic coercion by the State, while soft power is the cultural-ideological power of a country. The first is a command power, the second a co-optive power.

According to Nye $(2004,2010)$, the command power is the ability to change what others do. The command power manifests through coercion or State induction. Co-optive power, in turn, refers to the ability to modify the preferences of other

\footnotetext{
${ }^{4}$ Marx and Engels did not elaborate a Theory of the State. At the time when they analyzed the State, it really was nothing more than a platform for the interests of the bourgeois class.

${ }^{5}$ There is a whole branch of Political Science to be devoted to studies of class conciliation within the State, such as Corporatism or Neocorporativism. States with class conciliation have recently been categorized and researched by Schmitter (1974), Cawson (1986) Monoilesco (1938).
} 
actors, to shape the thinking of others so that they act in a certain way according to the will of the State.

Command power - the ability to change what others do - can rest on coercion or inducement. Co-optive power - the ability to shape what others want - can rest on the attractiveness of one's culture and values or the ability to manipulate the agenda of political choices in manner that makes others fail to express some preferences because they seem to be too unrealistic. (Nye, 2004, p. 7)

Nye's categorization $(2004,2010)$ refers to the ideas of the Italian political philosopher Antonio Gramsci about State hegemony by "force" or "consensus". For Gramsci (1987), the power of the State manifests itself more widely within political society and civil society, thus being a dynamic process constantly constructed and contested through different forms of class struggle and counter-hegemonic initiatives at various levels of the relation of forces both international and local groupings.

In this view, there is always a dispute between local and foreign social forces (States, corporations, non-governmental organizations, international organizations, social classes, social movements, employers' movements, etc.) for a certain control of this meta-field. The effort to command the agents and acts, which integrate the meta-capital and the meta-field - State - occurs by coercive or induction, that is, force or consensus and has as scope to seek a hegemony of power.

These relations of forces in the search for State control and the construction of meta-capital take place in two relations: i) domestic, State-society and ii) global., Inter-State - or in a Bourdieusian reading, Inter-meta-fields. The market, in turn, has become something present from the local to the global level since the TechnicalScientific-Informational Revolution in the mid-20th century. The tools and strategies that the States - understood here as a meta-field - use in the search for the accumulation of resources and powers - multiple modes of capital - both locally and internationally to influence and shape their relationship and interdependence with the market can be through the use of hard power and soft power.

It is possible to affirm that the conceptual formulation and operationalization of the State in contemporaneity, thus, can be summarized as the externalization of power (hard power or soft power) of some capital or several (material., cultural and social) in local and inter-meta-field level. Capitals are present in multiple field models with their agents and acts armed with rhetoric and "authorities," building a meta-field (in the historical-social procedurality of civilization the figure of the meta-field State prevailed) with its social expressions of political intermediation of agents, acts and establishing its legislation and norms, structuring a specific meta-capital. The metacapital., which is designed, can be that of market-rational., command economy or plan rational. A meta-field concerned with economic development is usually structured in the form of a National Developmental State, but there is nothing to prevent the meta-field from adopting another form of organization in the future. 


\section{PIONEERING ESSAYS OF THE NATIONAL-DEVELOPMENTAL META-FIELD}

Since the solidification of the Capitalist Revolution with the Industrial Revolution at the end of the 18th century, the role of the State has been changing. After the Industrial Revolution, the concept of the Nation-State was consolidated and acquired a rational and bureaucratic structure, sharing the role of coordination and regulation of the local economy with a new field and social class that emerged: national market and the bourgeoisie.

The Industrial Revolution, according to Charles Tilly (1975), was a consequence of the formation of the Nation-State and the expansion of the local market, now the national market. The Nation-State was the superior form of meta-field for the political-territorial organization. It was the model that agents and social groups with symbolic capital., therefore with more access to economic capital., cultural capital and social capital., consequently, greater powers (hard power and soft power) of the time found to concentrate military and ideological-cultural force, consolidating and expanding local markets. If, at first, control of the Nation-State was in the hands of the aristocracy, the military oligarchy, landowners and priests, with the commercial bourgeoisie orbiting and influencing around them; in a second moment, the Nation-State was taken over by the upper-middle bourgeois class ${ }^{6}$. The resources and powers of social activities had transmuted.

In societies where the Capitalist Revolution was already more advanced, such as Great Britain, France and Belgium; the new emerging financial., commercial and industrial class ordered and conducted the meta-field, in this case the Sovereign State and, subsequently, the Nation State through systems of economic and military alliances. In the pioneer countries in the Industrial Revolution, the fraction of the bourgeoisie that accumulated capital - coercive and inductive power - to exercise hegemony and to establish consensus, commanding the other groups by occupying the newly structured meta-field, was the emerging industrial class. The State, in these nations, experienced a dimension of stimulating the national manufacturing sector. It was the birth of the National-Developmental State (Hunt, Sherman, 2005; Bresser-Pereira, 2017b).

The outcrop western Europe's industrial class, essentially from Great Britain, had its historical origin based on the export oriented industrial branches of the 16th century putting-out system (domestic manufacturing systems). According to Hunt and Sherman (2005, p. 29), the infant capitalist companies of the putting-out system from the beginning sought to ensure "[...] monopolistic positions from which they could exclusively exploit the market for their products".

In addition to the creation of monopolies, all Western European countries, dur-

\footnotetext{
${ }^{6}$ The text does not consider the terms bourgeois class or bourgeoisie to be synonymous with the productive social layer. The term "bourgeoisie" designates the dominant social class in the Capitalist Revolution and formed by owners of goods or capital.
} 
ing this period, enacted extensive legislation regulating foreign trade, providing tax exemptions, subsidies, various restrictions and regulations controls, favoring the production of local industries focused on exports. The recently formed meta-field - State, in the pioneer countries of the Industrial Revolution, interfered expressively in domestic production, forcing its expansion, integration and sophistication of the productive structure to discipline foreign trade and foreign capital.

The modern State had, in its origins, therefore, the consolidation of domination and developmental practices as the majority field and as the economic capital., represented by the bourgeoisie. Cultural and social capital were still maintained in aristocratic nobility and religion. Mercantilism - the first economic organization of the modern State - can be considered, according to Bresser-Pereira (2016a), in the inaugural historical form of the economic development strategy.

In today's wealthy countries, the State was initially absolute on the political level and mercantilist on the economic level. As a mercantilist, the State was nationalist, or, more precisely, developmental., combining economic nationalism with moderate State intervention in the economy. (Bresser-Pereira, 2017b, p. 174)

In a robust research on the economic thought of development, Hidalgo-Capitán (1998) also places the adoption of mercantilist economic policy by certain European nations in the 17th century as a historical landmark of the National-Developmental State. In the author's words:

Development Economics is often considered to be a scientific subdiscipline that does not appear until after World War II. However, the concern about development, in its different versions (wealth, material prosperity, progress, growth, etc.), and the attempt to understand how it is produced in order to achieve it, is not the patrimony of the economists of the second half of the 20th century. On the contrary, the concern starts much earlier; the 17th century could be set as the first moment in which, in a generalized way, people who were engaged in political and economic activities began to consider the problem of development and to express it in their writings. The mercantilists are therefore the genuine pioneers of development, the first to deal with the wealth of nations. (Hidalgo-Capitán, 1998, p. 14)

The main goal of the mercantile economic policy was the expansion and development of the national market. The historical experience shows that the economic development is a condition associated with the expansion of the local economy through foreign trade or the occupation and exploration of other territories - and occurs due to industrialization. As Hidalgo-Captain summarizes:

As far as development theory is concerned, the predominant objective of the mercantilists was what we might consider to be the acceleration of 
the growth rate of total production. To achieve this objective, it was postulated the efficient and full use of available factors, especially work as well as an increase in the stock of these factors and the technological and economic capacity to use them. The mercantilist authors assumed that it was not possible to achieve this dual objective unless the intervention of the State took place directly and indirectly. In the first case, they were specific actions to avoid certain evils or strengthen certain favorable situations; the indirect intervention was based on the creation of general conditions aimed at economic development, such as satisfactory money for economic activities and banking, tax, legal and transportation facilities. However, most of the State intervention focused on the regulation of foreign trade and the manufacturing sector, considered as strategic sectors whose favorable development would bring with it that of other less strategic and dependent sectors. The role of the State in the theory of mercantilist development is therefore essential. (Hidalgo-Capitán, 1998, p. 17)

It is possible to affirm that, for mercantilists, the meta-field has to interfere directly and indirectly to guarantee the economic development of their territory. When examining the historical experiences of industrialization and economic development carried out by the central economies, Rodrik (2005, 2007), Chang (2004, 2008, 2009), Reinert (2007) and Wade (1990) demonstrate that all countries that have managed to expand, integrate and sophisticate their productive structure have used some type of direct and indirect State intervention aimed at protecting their market and their infant industries. While the manufacturing sector of these economies was lagging behind or non-existent, the State erected protectionist barriers and sectoral promotion actions to industrialize or catching-up their economies, transmuting their comparative advantages.

According to Reinert (2007, p. 53): "History reveals how rich countries got rich by methods that by now had generally been outlawed by the 'conditionalities' of the Washington Consensus. [...] synonymous with neo-liberalism and 'market fundamentalism'." The author, when describing the economic policies that disseminated the wealth in Europe, and later in the other developed regions in the world, still affirms: "[...] the market was a force tamed, like the wind, for the purpose of reaching a defined goal or destination" (Reinert, 2007, p. 60). The mechanism found, by the bourgeoisie of the central economies, to tame this force - the market - was the construction of the meta-field of the Developmental State.

In Great Britain, for example, during the reign of Henry VII (1509-1547), the English State established, according to Chang (2004), an import substitution industrialization (ISI) strategy. In addition, a list of raw materials and semi-manufactured goods could not be exported easily. The intention of these measures were two: i) keeping commodity prices low for domestic manufacturers and ii) curbing the country's productive specialization in primary goods. The English State even banned the sale of raw materials in order not to harm the country's manufactures 
at certain times when the domestic supply of primary products was reduced. Elisabeth I (1558-1603) embargoed all exports of unprocessed wool by Britain, leading the manufacturers of the Netherlands to ruin. There was also a policy to attract artisans, academics, scientists and entrepreneurs from abroad, now known as brain gain policy (Chang, 2004, 2008, 2009; Reinert, 2007; Wade, 1990).

For decades, British exporters who found it difficult to compete in the international market had the right to refund taxes or to receive subsidies for the export of their goods. At the same time, measures were adopted to discourage imports. Several products, mainly manufactured, were banned from being imported and others had high customs duties. The objective was to protect Britain's major export industries from competition driven by foreign manufacturers, who were striving to conquer the English domestic market and other British-dominated markets abroad (Chang, 2004, 2008, 2009; Reinert, 2007; Wade, 1990).

For that reason, Great Britain systematically used tariff protection by imposing high taxes on manufactured products from other countries until the end of the 1820s, about "[...] two generations after the Industrial Revolution" (Chang, 2004, p. 44). The English yaw toward free trade and comparative advantages only occurred in 1860, with the Cobden-Chevallier Treaty on free trade between Britain and France. This took place 84 years after the release of Adam Smith's book An Investigation of the Nature and Causes of Wealth of Nations (1776), considered the founding landmark of Classical Liberal thought in economics, and 43 years after David Ricardo's presentation of the Theory of Comparative Advantages in his book Principles of Political Economy and Taxation (1817) ${ }^{7}$.

The transition of Britain's economy from mercantilism developmental to economic Liberalism did not prevent the English State from maintaining the trade follows the flag (colonial exclusive) imposed with the use of hard power in the colonies. The accumulation of goods and wealth arising from the colonial triangular trade model (Great Britain, Africa and the Americas) imposed by the English Developmental State was another pillar, alongside economic interventionism, which determined Britain's industrialization and development in the 17th and 18th centuries (Gonçalves, 2012).

Presumably, it is suggested that when Great Britain opened its market, at the end of the 19th century, the national manufacturing sector already had technological supremacy over other economies. The defence of economic Liberalism by the British was only possible at the expense of centuries of protectionism guided by a National Developmental State and by colonial exploitation (Chang, 2004; Reinert, 2007).

Another central and pioneering economy in the Industrial State Revolution was France. During the reign of Louis XIV (1643-1715), the French installed Colbertism to develop the country. Colbertism comes from the name of the Minister of State

\footnotetext{
${ }^{7}$ Smith's and Ricardo's works can be accepted as cultural capital accumulated by the liberal bourgeoisie that resulted in soft power.
} 
and Economy of France at the time, Jean-Baptiste Colbert. Colbertism advocated economic development by encouraging the production of luxury manufacturing for export. Colbert allocated resources for science and education, hired foreign workers (brain gain policy) to emulate products from neighboring countries, granted monopoly rights, invested in economic infrastructure, codified, centralized and extended specific production techniques. All of these measures were intended to increase the quality and productivity of French manufactured goods, particularly luxury products. The French State, as well as other European countries, stimulated industrial espionage, creating even the position of Inspector General of Foreign Manufactures responsible for organizing the theft of technologies from other economies (Chang, 2004; Reinert, 2007).

After the French Revolution (1789), the French State, especially during the Napoleonic period (1799-1815), promoted the country's industrial and technological development. After Napoleon Bonaparte's defeat at the Battle of Waterloo in 1815, the ideology of laissez-faire (economic liberalism) was gradually gaining ground within the meta-field established in France. The Developmental State had a brief resumption with Luis Napoleão Bonaparte (1852-1870) who adopted a policy of arbitration of social classes - Bonapartism - aiming at the country's economic development. With the fall of Napoleon III, the French meta-field, deluded by the cultural capital of the British liberals, turned to laissez-faire. The French economy, however, did not have a productive structure sophisticated enough to compete with other European economies, causing the country to face industrial stagnation in the 19th century (Chang, 2004; Reinert, 2007).

The French laissez-faire Era extended until the end of World War II in 1945. France definitively rescued the Developmental meta-field with the founding of the Fifth French Republic in 1958 with Charles de Gaulle, who held the presidency of France for ten years from 1959 to 1969. During his mandate, De Gaulle established an intense economic interventionism and adopted an industrial policy for the expansion, integration and sophistication of the productive structure aiming at the catching-up of France. De Gaulle credited the rapid advance of the Germans into French territory, during the World War II, for the high technological gap of the French industry compared to the German one. The French technological backwardness was due to decades of utopian economic policy based on the precepts of economic Liberalism, such as free trade and comparative advantages. For De Gaulle, in this way, industrialization was not only a question of competitiveness by markets, but of national security as well (Chang, 2004; Reinert, 2007).

At the beginning of the Capitalist and Industrial Revolution, the State was seen as a defender of the national market and as a driver of local companies and businesses. The relationship among State, industry and economic development, consequently, became a matter for appreciation by thinkers and politicians of the time. European economic thinkers were the first to realize that widespread wealth existed only in regions where agriculture played a marginal role and was seen as an unintended by-product, thus allowing society to allocate its factors of production in diverse manufacturing branches (Reinert, 2007). 
The Italian Antonio Serra in 1613, in his book A Brief Treatise on the Causes Which Can Make Gold and Silver Abound in Kingdoms Where There Are No Mines, was the first economic intellectual to analyze this phenomenon. In 1613 Serra proposed to analyze the reasons why the City-State of Naples was poor, although it was rich in natural resources; while the City-State of Venice was rich despite being built in a swamp. Serra's (2002) answer to explain the difference in economic development and welfare between Naples and Venice was in the number of manufactures that Venice owned. For the author, the various industrial branches that clustered around the City-State of Venice allowed the region to benefit from the Increasing Returns to Scale offered by industrial activities.

In Serra's view (2002), because Venice is a swamp, therefore not being rich in natural resources or agriculture, it forced the City-State to develop a diversity of industries, innovations, services and businesses, attracting qualified people and becoming prosperous. The City-State of Naples, in turn, due to its abundance of natural resources and strong agriculture, its economy suffered from Decreasing Returns to Scale. Serra was the first author to suggest the advantages of industrial production over agriculture - due to the greater risks and decreasing returns - and the first thinker to develop an embryonic Theory of Uneven Geographical Development (Serra, 2002; Reinert, 2007).

The first intellectual to study the role of the State - or in a Bourdieusian reading, meta-field - complementary to the market for a society to achieve industrial development was William Petty (1623-1687). In two short texts entitled Treatise on Taxes and Contributions (1662) and Political Arithmetic (1690), Petty presents on economic surplus, social division of labor, advancement of manufacturing productivity and investment in infrastructure as a set of economic policy practices that determine the reducing production costs and increasing the international power of each country. Because of these studies, particularly by establishing the direct relationship between the size of the economic surplus and the international power of each country, Karl Marx considered William Petty to be the founding landmark of classical political economics (Padula, Fiori, 2019).

Later, in the 18th century, the formulations of Alexander Hamilton - first secretary of the treasury of the United States of America (USA) - published in the Report of the Secretary of the Treasury of the United States, on the Subject of Manufactures (1791) - known as the Report on Manufactures - proclaimed protectionist economic measures of the State. The report advocated encouraging the domestic market to enable the installation and development of the USA manufacturing industry. According to Reinert (2007), the economic policy instruments defended by Hamilton were similar to those of Henry VII of Great Britain, that is, ISI and tariff protection.

For Hamilton (2000), foreign competition and the force of habit ${ }^{8}$ prevented new

\footnotetext{
${ }^{8}$ It is important to mention that Hamilton in the 18 th century considers the force of habit as an obstacle to the economic development of a society. In the 20th century, Bourdieu $(1977,2007)$
} 
industries from developing in the USA. The State, according to Hamilton (2000), had to protect the new national industries, at first, by means of import tariffs or even by decreeing a ban on importing certain products. The objective was to allow the local productive structure to become more sophisticated and to have a greater division of labor, providing better competitiveness with foreign products. Hamilton is considered by Freeman (1989) and Bairoch (1993) as the first intellectual to structure a mature rhetoric about the protection of the "infant industry".

Although Petty's studies on economic surplus and Hamilton's on protectionism are substantial for understanding developmental strategies, it was only in the 19th century, with the writings of Friedrich List, in Germany, that a set of ideas with a clear proposal for express a theory with a really National-Developmental worldview was formally structured ${ }^{9}$. List, in his work The National System of Political Economy (1841), conducts a historical and inductive study of the commercial and industrial policies of the main Western economies of the time and rescues the analyses of the Increasing Returns to Scale offered by industrial activities developed by Serra (1613).

By analysing the historical experiences of economic development of countries such as Great Britain, Nederland, Portugal., Spain, France, USA, Italian States, the cities of the Hanseatic League and Germany; List (1983) concludes that Great Britain was the first country to adopt a systematic policy to protect the infant industry, conquering technological supremacy over other regions and States. Only after realizing their industrialization and transmuting their comparative advantages, the Britain began to propagate Smith's and Ricardo's theses of economic Liberalism.

For List (1983), the "individual economy" and the "cosmopolitan economy", based on the studies of Smith and Ricardo, by proclaiming ideas of universal peace, of comparative advantages, of invisible hands of the market and of free trade among the nations ignore important issues of asymmetries of power, wars and national interests. This mechanistic and utopian view of the economy was responsible, according to List (1983), to derail the development of technologically backward nations and to condemn them to British economic power.

The British rhetoric of economic Liberalism and the use of comparative advantages, for List (1983), is nothing more than a "cosmopolitan doctrine". In other words" $[\ldots]$ a very common and intelligent expedient of those who reached the top

formalized the concept of habitus as an open system of dispositions, actions and perceptions acquired by individuals over time and impacting their structural relations with the field and with the set of capital. Habitus is an incorporated cultural capital. "[...] the concept of habitus [...] corresponds to a matrix, determined by the individual's social position that allows him to think, see and act in the most varied situations. In this way, habitus translates lifestyles, political., moral and aesthetic judgments. It is also a means of action that allows the creation or development of individual or collective strategies" (Vasconcelos, 2002, p. 79).

${ }^{9}$ With List (1841), developmental cultural capital gains a strong and consolidated rhetoric as a resource of power. 
of the magnitude to kick the ladder down which has risen in order to prevent others from doing the same" (List, 1885, p. 295-296, in Chang, 2004, p. 17). By advocating and publicizing free trade and comparative advantages to other States, the British are using soft power - a co-optative command of ideological-cultural persuasion - to concentrate economic capital., cultural capital and social capital., thereby maintaining its meta-field superior to the others.

List's criticism of economic liberalism is not absolute and incomplete. The author recognizes that the Smith's and Ricardo's model may be convenient in some cases. In List's (1983) perception, free trade and comparative advantages are only beneficial among economies of similar level of industrial development, but not among economies with unequal productive structures. Considering this from another angle, according to Reinert (2007, p. 72$)$ : "Free trade [...] is necessary to create wealth in many contexts, but in others it reduces the wealth of a nation".

For that reason, it would be up to the State to seek to develop infrastructure, national political power, security and national order; in addition to investing in intellectuals, seeking harmony between laws and institutions and, above all, building a diversified, active and harmonious industry with trade and agriculture. List (1983, p. 101) calls this set of actions "the productive forces of the nation", which are responsible not only for the wealth of a country, but they are the real wealth of the nation. The State must optimize the production of productive powers and not exchange values. In 1871, with the unification of Germany, List's ideas contributed to the adoption of a successful State industrialization and development policy (Padula, Fiori, 2019).

According to Jaguaribe (1969), Germany, under the command of Otto von Bismarck (1815 - 1898), established a National Developmental State that was able to arbitrate and associate sectors of the land-owning aristocracy, progressive and bourgeois classes, as well as workers. The "Bismarckian" Developmental State combined intervention through investment banks, national market reserve for local manufactures and arbitration among the conflicting social forces. The success of this strategy made the policies implemented in Germany serve as a reference for other nations, such as Japan, Russia, Italy and the Nordic countries (Jaguaribe, 1969; Fiori, 2014; Bresser-Pereira, 2018).

Since List's formulation, in the 19th century, the concept of economic development has been approached by several theorists and is constantly present in the political-economic discourse. The State started to be conceived not only as holder of the monopoly of legitimate physical coercion in a given territory or as an exclusive platform of action for a certain social class. However, it can be thought of from profuse forms of capital as a resource and power (economic, cultural and social., generating hard and soft power) conducted by its agents and acts. The meta-capital that is formed has the potential to act in different fields and to establish the process of planning and executing a project of collective living in search of converging interests and needs, for example, the search for economic development. It is through the State, a meta-field built by various forms of capital., that the political will of society is met. 


\section{FINAL REMARKS}

The article sought to demonstrate that the formulation of the concept and the social-historical structuring of society around the State is a recent process. Despite being a recent phenomenon, it was from the construction of the meta-field, the State, that societies were able to enhance, through the intervention for ordering, their local markets and their economy as a whole. From this, there was the narrow and complex interdependence existing between the constitution of the State - meta-field with its political., economic and social arrangements - and the market.

The first communities that advanced to societies and, later, to peoples organized in a Nation-State and that managed to gather all capital (economic, cultural and social) in a meta-field capable of relating virtuously with the market were able to expand, to integrate and to sophisticate its productive structures. This achievement established the existence of central and peripheral economies, colonizers and colonized, imperialist and exploited, political-economic independence and politicaleconomic dependence, in short, forged a new social., political and economic structure between and within fields and capital - in Bourdieu's terms.

In the first section, it was verified that the relations guided by a capitalist ethic and organized by the State emerged during the Renaissance and consolidated itself as a meta-field guarantor of the advance of the Capitalist Revolution and for the concentration of capitals around a new class, the bourgeoisie, and operating in a new space, the national market. This new meta-field managed, in certain territories, to gradually build the identity of the nation and to establish a "common destiny" with the objective of national autonomy, internal public order and economic development. For that, the capital relations, which disputed the control of this new meta-field, had to process the accumulation of resources and powers - multiple modes of capital - in two dimensions: i) domestic, State-society and ii) international., Inter-State - or in a Bourdieusian reading, Inter-meta-fields. Thus, they used hard power and soft power according to their availability and capabilities.

In the second section, the article was based on scientific research based on historical and social facts, demonstrating that the formation of a developmental metafield and its relationship with the market was an elementary premise for the economic development of countries considered developed nowadays. These researches are not confused with individual or class information or opinions, but are accurate analyzes of the objective historical and social reality as it is. Consequently, it can be deduced that the Liberal rhetoric about economic development underestimates the historical-social procedurality - presented in this research - and falls into the ideological-political and subjective analysis. In other words, Liberals create specific theoretical elaborations based on what they want as the world to be like and/or essays for exercise soft power internally in the capitals and among the meta-fields.

The studies, cases and authors employed in this article employ a concrete and inductive analysis of economic history, therefore they are committed to objective research, rigorously carried out, based on real and concrete facts, studies in which 
the hypotheses and theories taken from the observations of the phenomena about economic development can be confirmed according to the analysis of reality. Meanwhile, the precepts of conventional orthodoxy are based on results from abstract and deductive analytical methods, often biasing into ideopolitical., subjective models with the function of exercising co-optive command of ideological-cultural persuasion - to concentrate economic capital., cultural capital and social capital., consequently maintaining the developed countries' meta-field superior to the others.

Finally, the research believes that it was able to answer your question and validate your hypothesis. In addition to contributing satisfactorily to the transdisciplinarity of scientific knowledge by employing studies of Social Science - sociological theory by Pierre Bourdieu - and Economic Science - historical perspective and studies on the National Developmental State. This, however, is not to say that the research obtained complete and integral coverage of the theoretical framework and the object studied, new studies with these theoretical and conceptual tools are fundamental in the future. I hope this research will encourage this.

\section{REFERENCES}

AMSDEN, A. H. (2001). The Rise of "The Rest": Challenges to the West from Late-Industrializing Economies. New York: Oxford University Press.

BAIROCH, P. (1993). Economics and World History: myths and paradoxes. Chicago: The University of Chicago Press.

BAUER, O. (2000). A nação. In: BALAKRISHNAN, G. (org.). Um mapa da questão nacional. Rio de Janeiro: Contraponto.

BONAVIDES, P. (2008). Reflexões sobre nação, Estado social e soberania. Estudos Avançados, São Paulo, v. 22, n. 62, p. 195-217.

BOURDIEU, P. (2007). A economia das trocas simbólicas. São Paulo: Perspectiva.

BOURDIEU, P. (1998). Practical Reason: On the Theory of Action. California: Stanford University Press.

BOURDIEU, P. (1977). Outline of a theory of practice. Cambridge, Cambridge University Press.

BOURDIEU, P. (2014). Sobre o Estado: cursos no Collége de France (1989-92). São Paulo: Companhia das Letras.

BRANCALEONE, C. (2008). Comunidade, Sociedade e Sociabilidade: Revisitando Ferdinad Tönnies. Revista de Ciências Sociais, Florianópolis, v.39, n.01, p. 98-104.

BRESSER-PEREIRA, L. C. ( 2016a). Modelos de estado desenvolvimentista. Textos para Discussão da Escola de Economia de São Paulo da Fundação Getulio (FGV-EESP), São Paulo, n.42, p. 1-23.

BRESSER-PEREIRA, L. C. (2016b). A construção política do Brasil: Sociedade, economia e Estado desde a Independência. São Paulo: editora 34.

BRESSER-PEREIRA, L. C. (2018). Em busca do Desenvolvimento perdido: um projeto novo-desenvolvimentista para o Brasil. São Paulo: FGV.

BRESSER-PEREIRA, L. C. (2017a). The two forms of capitalism: developmentalism and economic liberalism. Brazilian Journal of Political Economy, São Paulo, vol.37 nº.4, p. 680-703.

BRESSER-PEREIRA, L. C. (2017b). Estado, Estado-Nação e formas de intermediação política. Revista Lua Nova, São Paulo, n. 100, p. 155-185.

CARCANHOlO, M. D. (2013). O atual resgate crítico da Teoria Marxista da Dependência. Trab. Educ. Saúde, Rio de Janeiro, v. 11 n. 1, p. 191-205, jan./abr. 
CASTRO, M. F. (2001). Caderno no 20: De Westphalia a Seattle: a Teoria das Relações Internacionais em transição. Cadernos do REL. Brasília: UnB.

CHANG, H.J. (2008). Bad samaritans: The guilty secrets of rich nations \& the threat to global prosperity. London: Randon House.

CHANG, H.J. (2004). Chutando a escada: a estratégia do desenvolvimento em perspectiva histórica. São Paulo: Unesp.

CHANG, H.J. (2009). Hamlet without the Prince of Denmark: How development has disappeared from today's 'development' discourse.

DURKHEIM, É. (1960). De la division du travail social. Paris: Presses Universitaires de France.

FIORI, J. L. (2014). História, estratégia e desenvolvimento: para uma geopolítica do capitalismo. São Paulo: Boitempo.

FREEMAN, C. (1989). New Technology and Catching-up. European Journal of Development Research, v.1, n.1, p. 85-99.

GONÇALVES, R. (2012). Novo Desenvolvimentismo e Liberalismo Enraizado. Revista Serviço Social \& Sociedade, São Paulo, n.112, p. 637-671, out/dez.

GRAMSCI, A. Cartas do Cárcere. (1987). Rio de Janeiro: Civilização Brasileira.

HAMILTON, A. (2000). Relatório sobre as Manufaturas. Rio de Janeiro: MSIA.

HIDALGO-CAPITÁN, A. L. (1998). El Pensamiento Económico sobre Desarrollo. Tese (Doutorado). Universidad de Huelva, Espanha.

HOBSBAWM, E. (2004). Nações e nacionalismo desde 1780: programa, mito e realidade. Rio de Janeiro: Nova Fronteira.

HUNT, E.K; SHERMAN, H. J. (2005). História do pensamento econômico. Petrópolis: Vozes.

JAGUARIBE, H. (1969). Desenvolvimento Econômico e Desenvolvimento Político. Rio de Janeiro: Paz e Terra.

LIST, F. (1983). Sistema Nacional de Economia Política. São Paulo: Abril Cultural.

MANOILESCO, M. (1938). O Século do corporativismo: doutrina do corporativismo integral e puro. Rio de Janeiro: José Olympio.

MARX, K.; ENGELS, F. (1998). The German Ideology. New York: Prometheus Books.

MARX, K.; ENGELS, F. (2010). Manifesto of the Communist Party. London: Andy Blunden, 2004.

NYE Jr, J. S. (2012). O futuro do poder. São Paulo: Benvirá.

NYE Jr, J. S. (2004). Soft power: the means to success in World Politics. New York: Public Affairs.

PADULA, R.; FIORI, J. L. (2019). Geopolítica e Desenvolvimento em Petty, Hamilton e List. Revista de Economia Política, São Paulo, vol. 39, nº 2 (155), p. 236-252.

PETTY, W. (1983). Tratado dos Impostos e Contribuições. São Paulo: Abril Cultural.

PETTY, W. (1983). Aritmética política. São Paulo: Abril Cultural.

REINERT, E. S. (2007). How Rich Countries Got Rich.... and Why Poor Countries Stay Poor. New York: Hachette Book.

RENAN, E. (1997). O que é uma nação? In: ROUANET, M. H. (org.) Nacionalidade em questão. Rio de Janeiro: UERJ.

RODRIK, D. (2005). Growth strategies. In: AGHION, P. ; DURLAUF, S. Handbook of economic growth. Amsterdam: North-Holland.

RODRIK, D. (2007). One Economics, Many Recipes: Globalization, Institutions, and Economic Growth. Princeton: Princeton University Press.

SERRA, A. (2002). Breve tratado das causas que podem fazer os reinos desprovidos de minas ter abundância de ouro e prata (1613). Curitiba: Segesta Editora.

TILLY, C. (1975). Western State-making and theories of political transformation. In: TILLY, C. (org.). The formation of national States in Western Europe. Princeton: Princeton University Press.

TÖNNIES, F. (1947). Comunidad y Sociedad. Buenos Aires: Losada.

TORREGGIANI, V. (2016). Rediscovering The Guild System: The New Age Circle as a British Labora- 
tory of Corporatist Ideas (1906-1916). Oficina do Historiador, Porto Alegre, EDIPUCRS, v. 9, n. 2, jul./dez. p. 25-42.

VASCONCELOS, M. (2002). D. Pierre Bourdieu: A herança sociológica. Educação \& Sociedade, vol. 23, $\mathrm{n}^{\circ} 78$, Campinas, p. 77-87.

WADE, R. (1990). Governing the market: economic theory and the role of government in East Asian industrialization. Princeton: Princeton University Press.

WEBER, M. (1982). Ensaios de sociologia. Rio de Janeiro: Zahar. 